\title{
Oxygenic photosynthesis as driving process in exopolysaccharide production of benthic diatoms
}

\author{
Natascha Staats ${ }^{1, *}$, Lucas J. Stal ${ }^{2}$, Ben de Winder ${ }^{1, * *}$, Luuc R. Mur $^{1}$ \\ 'Department of Microbiology/ARISE, University of Amsterdam, Nieuwe Achtergracht 127, 1018 WS Amsterdam, \\ The Netherlands
}

${ }^{2}$ Netherlands Institute of Ecology, Centre for Estuarine and Coastal Ecology, PO Box 140, 4400 AC Yerseke, The Netherlands

\begin{abstract}
The secretion of exopolysaccharide in an axenic culture of the marine benthic diatom Cylindrotheca closterium was investigated. The central question of the experiments was if polysaccharide secretion was dependent on light and photosynthesis. Cells were incubated in the light, in the dark, or in the light with addition of the inhibitor of Photosystem II, 3-(3,4-dichlorophenyl)-1,1-dimethyl urea (DCMU). These treatments were also applied to a population of benthic diatoms on an intertidal mudflat in the Westerscheide (Scheldt estuary, The Netherlands). In the light $\left(60 \mu \mathrm{mol}\right.$ photons $\left.\mathrm{m}^{-2} \mathrm{~s}^{-1}\right)$ C. closterium showed high rates of polysaccharide secretion, while no secretion was observed in the dark or in the presence of DCMU. No intracellular carbohydrate was converted to exopolysaccharide in the dark or in the light with DCMU added. This indicated that secretion of exopolysaccharide was dependent on oxygenic photosynthesis. Similarly, high rates of exopolysaccharide accumulation were observed during daytime emersion on the mudflat, but not in darkened or DCMU-treated sediment. This demonstrated that the pattern observed in cultures of C. closterium was reproducible in situ. It was observed that during daytime emersion patterns of vertical migration in the dark and DCMU-treated plots did not differ from those in the light. This implies that motility was not the steering factor for the observed accumulation of exopolysaccharide in the light. When an axenic culture of $C$. closterium was

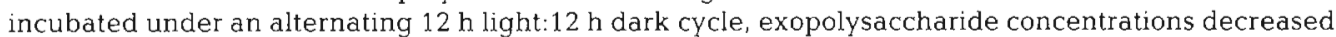
in the dark. Degradation of exopolysaccharide was also observed in the natural population on the mudflat during emersion at night. Because no bacteria were present in the C. closterium cultures, it was conceived that the degradation of exopolysaccharide observed in cultures was due to secretion of hydrolytic enzymes by $C$. closterium.
\end{abstract}

KEY WORDS: Cylindrotheca closterium - Diatoms - Exopolysaccharide - Extracellular polymeric substances - Intertidal sediments - Microphytobenthos - Photosynthesis · Polysaccharide

\section{INTRODUCTION}

Benthic diatoms inhabiting intertidal sediments produce large amounts of extracellular polymers, also denoted as EPS or mucilage, which mainly consist of polysaccharides (Decho 1990, Hoagland et al. 1993). Epipelic species (motile species which are predominantly found in sediments with a small grain size) are

\footnotetext{
Present addresses:

'Max Planck Institute for Marine Microbiology, Celsiusstr.1,

28359 Bremen, Germany. E-mail: nstaats@mpi-bremen.de

- Ministry of Public Works, RIKZ-RWS, PO Box 8039, 4330

EA Middelburg, The Netherlands
}

particularly well known for their large production of exopolysaccharide (Hoagland et al. 1993). The secretion of exopolysaccharide by epipelic diatoms has been shown to contribute to stabilization of the sediment, thereby increasing resistance towards erosion (Holland et al. 1974, Vos et al. 1988, Paterson 1989, Sutherland et al. 1998). Small sediment particles are trapped in the exopolysaccharide matrix, probably through interactions with sugars substituted with acidic groups (Dade et al. 1990).

The function of exopolysaccharide production for the diatoms is not precisely known. Several functions have been conceived, such as protection against desiccation or grazing, scavenging inorganic nutrients or metals, 
or attachment. Epipelic diatoms (mud-dwelling species) show extensive motility (Mcintyre \& Moore 1977). Since epipelic species generally produce more exopolysaccharide than non-motile (epipsammic) species (Hoagland et al. 1993) it has also been suggested that exopolysaccharide secretion is associated with motility (Harper 1977, Edgar \& Pickett-Heaps 1984, Hoagland et al. 1993). It has also been shown that carbohydrate secretion by diatoms was dependent on abiotic factors such as nutrients (Myklestad \& Haug 1972, Myklestad 1977. Waite et al. 1995, Sutherland et al. 1998). In addition, benthic diatoms are subject to large variations in light intentsity (Fenchel \& Straarup 1971, Pinckney \& Zingmark 1991), which may also influence exopolysaccharide production. However, the amount of work done on the effect of light on exopolysaccharide production is still limited.

In the present investigation, experiments are described that study the dependence of exopolysaccharide production by benthic diatoms on light and photosynthesis. The main questions of the experiments were: (1) Are polysaccharides only secreted in the light, or also in the dark? (2) Are polysaccharides secreted when photosynthesis is inhibited? and (3) What is the effect of light intensity on exopolysaccharide production? The approach that was taken was to incubate cells in the light, in the dark, or in the light with addition of a photosynthesis blocker. These treatments were applied not only to axenic cultures of $C y$ indrotheca closterium, but also to a natural diatom community on an intertidal mudflat in the Westerschelde (Scheldt estuary, The Netherlands). Furthermore, polysaccharide secretion during a light:dark cycle was monitored, both in cultures and in situ. Also, the effect of different light intensities on secretion was studied in cultures of $C$. closterium.

\section{MATERIALS AND METHODS}

Organism and culture conditions. A strain of Cylindrotheca closterium (Ehrenb.) Reimann \& Lewin isolated from the Ems-Dollard area (The Netherlands) was kindly provided by $\mathrm{H}$. Peletier (RIKZ, Haren, The Netherlands). Cells were grown in Kester medium (Kester et al. 1967) at a salinity of 33 PSU. Cells were cultivated on a solid substratum of purified sea sand (Merck, Darmstadt, Germany) in 300 or $1000 \mathrm{ml}$ glass Erlenmeyer flasks at $20^{\circ} \mathrm{C}$. Cultures were illuminated by 2 white fluorescent tubes (Philips TLE 32/33) which gave an incident irradiance of $60 \mu \mathrm{mol} \mathrm{m}^{-2} \mathrm{~s}^{-1}$ at the surface of the culture flask. Axenicity of the cultures was checked by plating on agar/medium and by microscopic observation.

Conditions of culture experiments. The effect of light and dark treatment and of the inhibitor of oxy- genic photosynthesis 3-(3,4-dichlorophenyl)-1,1-dimethyl urea (DCMU) was investigated in an axenic culture which was grown under continuous light at an incident irradiance of $60 \mu \mathrm{mol}$ photons $\mathrm{m}^{-2} \mathrm{~s}^{-1}$. Early stationary phase cells were used because during the logarithmic growth phase there was no production of exopolysaccharide, whereas during the transition towards stationary growth the production rate was high (Staats et al. 1999). In order to establish a dark to light transition that would correspond to natural conditions, the culture was incubated in the dark for $10 \mathrm{~h}$ before the start of the experiment. The culture was then divided into experimental subcultures. These were incubated either in the light $\left(60 \mu \mathrm{mol}\right.$ photons $\mathrm{m}^{-2}$ $\mathrm{s}^{-1}$, in the light with $10^{-5} \mathrm{M} \mathrm{DCMU}$, in low light (15 $\mathrm{mmol}$ photons $\mathrm{m}^{-2} \mathrm{~s}^{-1}$ ) or in the dark. The stock solution of DCMU $\left(10^{-2} \mathrm{M}\right)$ was made up in $70 \%$ ethanol. This treatment resulted in a final concentration of $0.07 \%$ ethanol. Therefore a control subculture was incubated with a final concentration of $0.07 \%$ ethanol. Low light conditions were obtained by wrapping a 2-stop neutral density filter (Capilux. Amsterdam) around the culture flask. Complete darkness was obtained by wrapping the culture flask in several layers of aluminium foil. At the start of the experimental incubations the starting culture was harvested. At frequent intervals during the incubations, samples were taken from the subcultures. To harvest cells, cultures were gently shaken until all cells had gone into suspension. Subsequently, the sand was allowed to settle before the cell suspension was poured off.

In another experiment the culture was grown under an alternating $12 \mathrm{~h}$ light: $12 \mathrm{~h}$ dark cycle (incident irradiance: $60 \mu \mathrm{mol}$ photons $\mathrm{m}^{-2} \mathrm{~s}^{-1}$ ). When the culture had reached early stationary phase, samples were taken every 3 h during 1 light:dark cycle.

All treatments were performed twice in independent runs to ensure reproducibility. Level of significance of differences between time points or between treatments of the variables analyzed were tested using analysis of variance (Sokal \& Rohlf 1981).

Isolation of exopolysaccharide from cultures. Two fractions of exopolysaccharide were distinguished. A detailed description of isolation and characterization of these fractions is given in Staats et al. (1999). These fractions differed in composition and showed different patterns of accumulation during a growth curve (Staats et al. 1999). The fraction that was not or only loosely attached to the cell surface was obtained by centrifuging the cell suspension for $15 \mathrm{~min}$ at $20000 \times g$ and $10^{\circ} \mathrm{C}$. The supernatant was designated 'non-attached exopolysaccharide'. This fraction showed no concentration changes during a growth curve (Staats et al. 1999). Subsequently, the pellet was incubated with tap water for $1 \mathrm{~h}$ at $30^{\circ} \mathrm{C}$ and centrifuged 
for $15 \mathrm{~min}$ at $20000 \times g$ and $10^{\circ} \mathrm{C}$. This extract contained carbohydrates that were closely associated with the cells, which were designated 'attached exopolysaccharide'. The production rate of this fraction strongly increased during the transition towards stationary growth (Staats et al. 1999). It was shown that neither of the 2 fractions was contaminated with intracellular carbohydrate (Staats et al. 1999). Polymers were isolated from both fractions by overnight precipitation in cold $\left(-20^{\circ} \mathrm{C}\right) 80 \%(\mathrm{v} / \mathrm{v})$ ethanol. The precipitate was dried under a flow of nitrogen gas and stored dry at $-20^{\circ} \mathrm{C}$ until analysis. In some cases part of the supernatant of the ethanol-treated sample was also dried under nitrogen gas and stored at $-20^{\circ} \mathrm{C}$. This yielded low molecular weight (LMW) carbohydrates (monomers and oligomers), which did not precipitate in cold $80 \%(\mathrm{v} / \mathrm{v})$ ethanol. One experiment was performed in which concentrations of polysaccharide and LMW carbohydrate were monitored in an extract of attached extracellular carbohydrate, incubated in the absence of cells. The extract was isolated halfway through the dark period from an axenic culture that had been grown under a $12 \mathrm{~h}$ light:12 h dark cycle. The extract was incubated in triplicate under sterile conditions.

Analyses of cultures. Cells were counted in triplicate using a Coulter counter (model ZM) equipped with a 50 $\mu \mathrm{m}$ aperture tube. Cell protein was determined in triplicate on freeze-dried cells by the Lowry method (Herbert et al. 1971) using bovine serum albumin (BSA) as a reference. Intracellular carbohydrate was determined after extracting the extracellular carbohydrates as described above and freeze-drying the remaining pellet. Extracellular carbohydrate was analyzed using the phenol/ $/ \mathrm{H}_{2} \mathrm{SO}_{4}$ assay with glucose as a standard (Dubois et al. 1956). The phenol/ $\mathrm{H}_{2} \mathrm{SO}_{4}$ assay was generally preferred as a 'total carbohydrate' assay, because it analyzes pentoses and hexoses (Dubois et al. 1956) but appeared less suitable for analysis of whole algal cells. Therefore total hexose content of the pellets was determined with the Anthrone reagent using glucose as a standard (Herbert et al. 1971). Since cell carbohydrate consisted mainly of hexoses (Staats et al. 1999) these methods were quantitatively comparable.

Site of field experiments. Field experiments were performed on a tidal mudflat near Ellewoutsdijk, in the northern part of the Westerschelde (Scheldt estuary, The Netherlands). The sediment was composed of silt and the surface was covered with a dense biofilm of benthic diatoms. Salinity of the pore water was 31 PSU, measured with a refractometer (Atago). Light intensity at the field site was measured using a Li-250 light meter (Li-Cor).

Sampling of natural population. The field experiment was carried out in May 1997. Immediately upon tidal emersion 3 plots of $2 \mathrm{~m}^{2}$ were marked on the mudflat. The 3 plots were situated close together and did not appear to differ in morphology. One plot was darkened using black plastic foil. The second plot was sprayed evenly with a solution of DCMU. The solution was prepared by diluting a $10^{-2} \mathrm{M}$ stock solution prepared in $70 \%$ ethanol to $10^{-5} \mathrm{M}$ in $33 \mathrm{~g} \mathrm{l}^{-1} \mathrm{NaCl}$, approximating the salinity of the pore water. The final concentration of $0.07 \%$ ethanol in the solution applied to the sediment did not have any deleterious effects on growth or exopolysaccharide production in cultures of Cylindrotheca closterium. Therefore it was assumed that this would also be the case in sediment. The third plot was left untreated. The plots were sampled immediately after treatment and subsequently at intervals of 2 to $3 \mathrm{~h}$. From each plot, replicate cores were taken randomly $(n=10)$ using stainless steel corers of $1.75 \mathrm{~cm}$ diameter. The sample sediment surface remained undisturbed by pressing the corer into the sediment, closing it airtight with a rubber stopper and lifting the corer. Immediately after the cores were taken, the top $2.5 \mathrm{~mm}$ were sliced using a custom-made slicer and stored on ice in the dark. Sampling was continued for a $24 \mathrm{~h}$ period with the exception of the immersion periods. When the experiment was completed samples were taken to the laboratory and stored at $-20^{\circ} \mathrm{C}$. Level of significance of differences between time points or between treatments of the variables analyzed was tested using analysis of variance (Sokal \& Rohlf 1981).

Isolation and analysis of exopolysaccharide from sediment. Prior to analysis, sediment samples were freeze-dried. To approximately $100 \mathrm{mg}$ of dry sediment, $1.5 \mathrm{ml}$ of distilled water was added, followed by incubation at $30^{\circ} \mathrm{C}$ for $1 \mathrm{~h}$. Subsequently, the extract was centrifuged at $20000 \times \mathrm{g}$ and $10^{\circ} \mathrm{C}$ for $15 \mathrm{~min}$. As a second extraction step, the pellet was incubated with $1.5 \mathrm{ml}$ of a solution of $150 \mathrm{mM}$ EDTA at $20^{\circ} \mathrm{C}$ for $6 \mathrm{~h}$. The extract was centrifuged at $20000 \times g$ for $15 \mathrm{~min}$. From both the water and EDTA extracts high molecular weight (HMW) and LMW carbohydrates were separated by addition of ethanol to a final concentration of $80 \%(\mathrm{v} / \mathrm{v})$ and overnight incubation at $-20^{\circ} \mathrm{C}$. The precipitate (HMW) and the supernatant (LMW) were dried under a flow of nitrogen gas and stored at $-20^{\circ} \mathrm{C}$ until analysis. The carbohydrate concentration of the fractions was assayed using the phenol/ $\mathrm{H}_{2} \mathrm{SO}_{4}$ assay with glucose as a standard (Dubois et al. 1956).

Isolation and analysis of chlorophyll a (chl a) from sediment. To approximately $100 \mathrm{mg}$ of freeze-dried sediment, $0.7 \mathrm{ml}$ of $\mathrm{N}, \mathrm{N}$-dimethylformamide (DMF) was added. Samples were incubated for $1 \mathrm{~h}$ in the dark. After centrifugation at $20000 \times g$ for $5 \mathrm{~min}$, the absorption of the extract was read at $665 \mathrm{~nm}$. To correct for phaeophytin, the absorption was read at $665 \mathrm{~nm}$ after adding $15 \mu \mathrm{l} \mathrm{HCl}(5 \mathrm{~N})$ to the $0.5 \mathrm{ml}$ 
extract. Concentrations were calculated according to the following equations (De Winder et al. 1999):

$$
\begin{aligned}
\operatorname{chl} a\left(\mathrm{gl}^{-1}\right) & =K \cdot\left(E_{\mathrm{a}}-E_{\mathrm{a}}\right) / A \\
\text { phaeophytin }\left(\mathrm{g} \mathrm{l}^{-1}\right) & =K \cdot\left(R \cdot E_{\mathrm{a}}-E_{\mathrm{n}}\right) / A
\end{aligned}
$$

with $E_{\mathrm{n}}=$ extinction neutral extract, $E_{a}=$ extinction acidified extract, $A=72.114, K=2.30$ and $R=1.80$. Values for $A, K$ and $R$ were experimentally obtained using purified chl $a$ and phaeophytin.

\section{RESULTS}

\section{Culture experiments}

The production of exopolysaccharide by an early stationary phase culture of Cylindrotheca closterium is shown in Fig. 1a. Within $2 \mathrm{~h}$, a significantly higher amount of polysaccharide was secreted in the light than in the dark, after transfer from darkness $(p<0.05)$. When the cells were incubated in the dark no secretion of polysaccharide was observed. When the inhibitor of
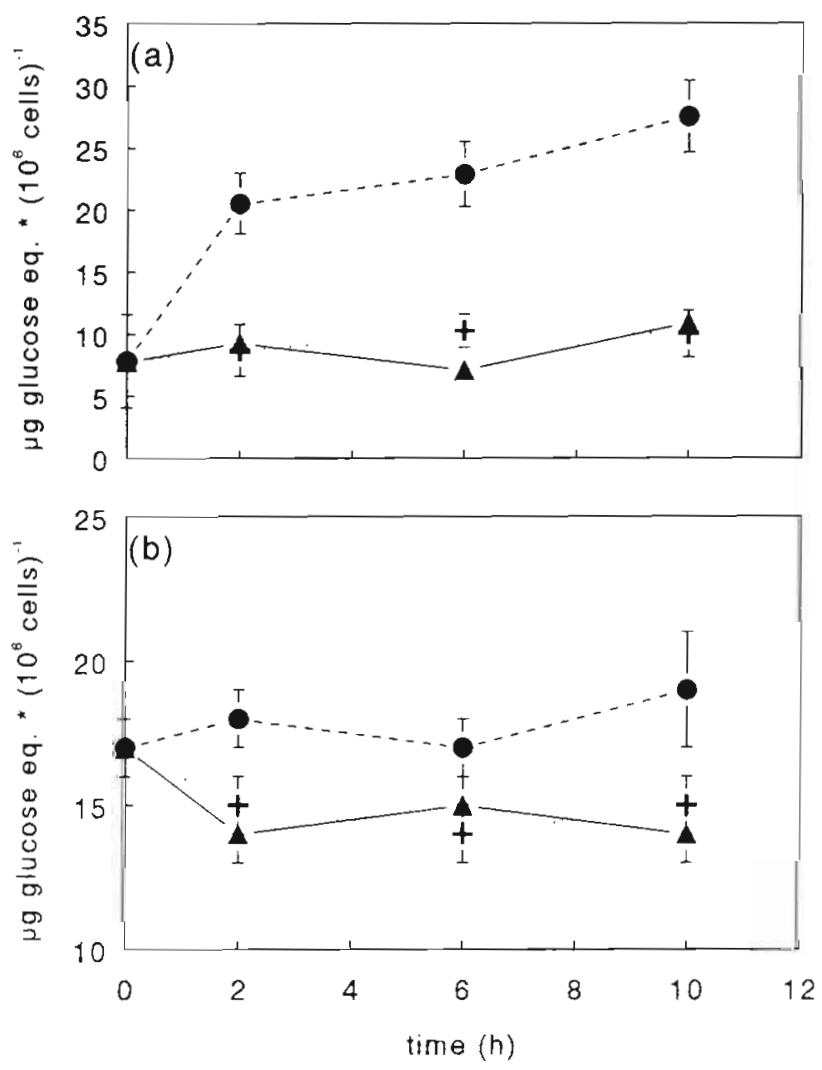

Fig. 1. Concentrations of (a) extracellular polysaccharide and (b) intracellular carbohydrate imean \pm SD of 3 replicate samplesi in cultures of Cylindrotheca closterium upon incubation in the light $\left(60 \mu \mathrm{mol}\right.$ photons $\left.\mathrm{m}^{-2} \mathrm{~s}^{-1}\right)(\mathbf{0})$, in the dark ( $\left.\mathbf{\Delta}\right)$ or in the light with addition of DCMU + )

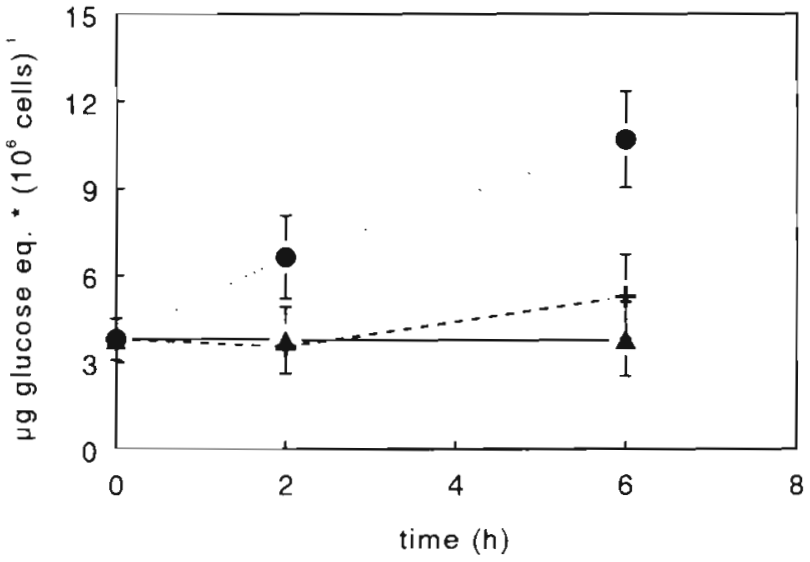

Fig. 2. Concentrations of extracellular polysaccharide (mean \pm $\mathrm{SD}$ of 3 replicate samples) in cultures of Cylindrotheca closterium upon incubation at $60 \mu \mathrm{mol}$ photons $\mathrm{m}^{-2} \mathrm{~s}^{-1}$ $15 \mathrm{\mu mol}$ photons $\mathrm{m}^{-2} \mathrm{~s}^{-1}(+)$ or in the dark

Photosystem II, DCMU, was added no exopolysaccharide was produced either. This was not an effect of ethanol, in which DCMU was dissolved. A control culture with the same final concentration of ethanol $(0.07 \%$ ) (not shown) did not differ from the culture incubated in the light without ethanol.

Changes in storage carbohydrates are shown in Fig. 1b. In the light, no changes in intracellular carbohydrates were observed. Both in the dark, as well as in the light in the presence of DCMU, a slight decrease of intracellular carbohydrate was noted during the first $2 \mathrm{~h}$ of incubation. However, a statistically significant difference ( $p<0.05$ ) was only found between the light and dark treatments after $2 \mathrm{~h}$. The control culture with $0.07 \%$ ethanol did not deviate from the light incubation (not shown). The fact that only a small decrease of intracellular carbohydrate was found in the dark was probably due to the fact that the stationary phase cells possessed low metabolic rates while having a high level of intracellular storage carbohydrate.

When comparing secretion of polysaccharides upon transfer from dark to light at 2 different levels of illumination ( 15 and $60 \mu \mathrm{mol}$ photons $\mathrm{m}^{-2} \mathrm{~s}^{-1}$ ), it was obvious that a minimum level of illumination was required for production of exopolysaccharide (Fig. 2). At an irradiance of $15 \mu \mathrm{mol}$ photons $\mathrm{m}^{-2} \mathrm{~s}^{-1}$ the amount of exopolysaccharide remained constant, as was the case in the dark, whereas at an irradiance of $60 \mu \mathrm{mol}$ photons $\mathrm{m}^{-2} \mathrm{~s}^{-1}$ a significantly higher amount of polysaccharide was measured after $6 \mathrm{~h}(\mathrm{p}<0.05)$.

The differences observed in both carbohydrate concentrations and accumulation rates between the control cultures depicted in Figs. 1a \& 2 may be explained by the small age difference between the cultures used in these experiments. Cultures were in the transition phase towards stationary growth, which was the phase 


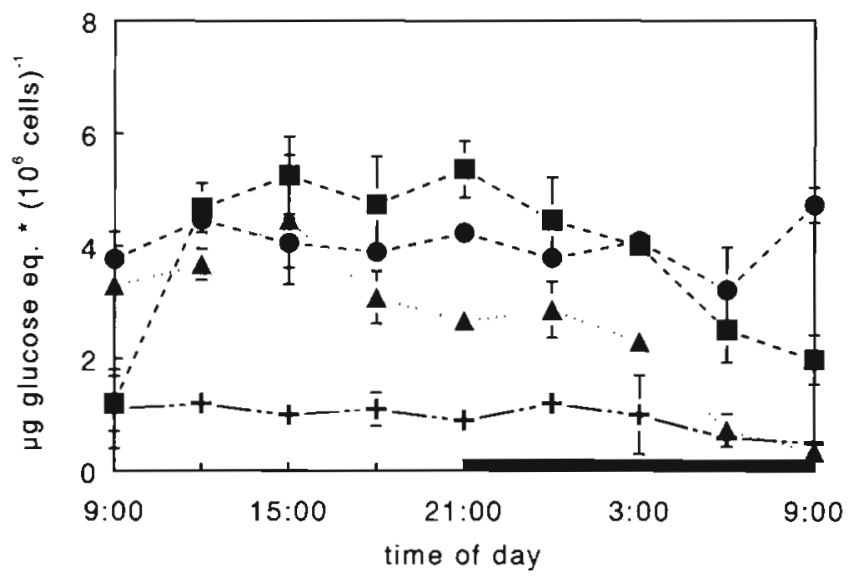

Fig. 3. Concentrations of attached extracellular polysaccharide ( $\mathbf{\square})$, non-attached extracellular polysaccharide $(\mathbf{A})$, total low molecular weight (LMW) extracellular carbohydrate (+) and intracellular carbohydrate (n) in a culture of Cylindrotheca closterium during a $12 \mathrm{~h}$ light: $12 \mathrm{~h}$ dark cycle. Dark period indicated by black bar. Values are mean \pm SD of 3 replicate samples

in which the rate of exopolysaccharide production started to increase (Staats et al. 1999). The culture incubated at $60 \mu \mathrm{mol}$ photons $\mathrm{m}^{-2} \mathrm{~s}^{-1}$ shown in Fig. 1a was slightly older $(8 \mathrm{~d})$ than the culture incubated at $60 \mu \mathrm{mol}$ photons $\mathrm{m}^{-2} \mathrm{~s}^{-1}$ shown in Fig. 2 (6 d), and therefore exhibited a higher exopolysaccharide accumulation rate (consequently, the initial concentration of exopolysaccharide was also higher).

In Fig. 3 concentrations of different carbohydrate pools in a culture grown under a $12 \mathrm{~h}$ light: $12 \mathrm{~h}$ dark cycle are shown. During the light period, concentrations of extracellular polysaccharide closely associated with cells significantly increased $(p<0.01)$, with the most pronounced increase during the first few hours after the onset of the light period (as was also observed in Fig. 1a). The concentration of the non-attached exopolysaccharide fraction, consisting of exopolysaccharide not associated with cells but found in the medium, did not exhibit any significant changes during the light period. Interestingly, both attached and non-attached exopolysaccharides showed a marked decrease during the dark period $(p<0.05$ and $p<0.01$, respectively). A small amount of extracellular LMW carbohydrates was found, which did not show any significant changes in concentration during the light period, but decreased significantly during the dark period ( $p<0.05$ ). It was remarkable that the pool of intracellular carbohydrates did not show any significant changes in concentration during the light:dark cycle.

In order to get a better insight into the decrease of attached exopolysaccharide observed during the dark period, an extract of attached extracellular carbohydrate was incubated in the absence of cells. In Fig. 4 concentrations of polysaccharide and LMW carbohydrate in this extract are shown. The polysaccharide fraction decreased significantly during the first $6 \mathrm{~h}$ ( $p<0.05$ ), while the amount of LMW carbohydrates significantly increased $(\mathrm{p}<0.05)$. The decrease in polysaccharide was completely balanced by the increase in LMW carbohydrate, and could therefore be explained by degradation (and not e.g. by polysaccharide sticking to the glass wall).

\section{Field experiments}

During the $24 \mathrm{~h}$ field experiment, the concentration of chl $a$ in the upper $2.5 \mathrm{~mm}$ during daytime emersion averaged $69 \pm 8 \mu \mathrm{g}$ (g sediment) $)^{-1}$. There were no significant differences in chl a concentration between the treatments or with time. In addition, there was no significant difference in chl a concentration before and after tidal emersion, concentrations in the control plot averaging $78 \pm 4 \mu \mathrm{g}$ (g sediment) ${ }^{-1}$ at night. This was taken as evidence that no growth or resuspension had occurred during the experiment. Microscopic observations showed that the major part of the diatom community consisted of epipelic species, with species of the genus Gyrosigma dominating.

Fig. 5a shows the concentrations of water-extractable polysaccharides in the upper $2.5 \mathrm{~mm}$ of sediment during a $24 \mathrm{~h}$ period. During the daytime emersion period, water-extractable polysaccharides increased considerably ( $p<0.05$ ). In the experimental plot that was darkened, concentrations of waterextractable polysaccharides did not change significantly during daytime emersion. In the plot treated with DCMU, concentrations of water-extractable poly-

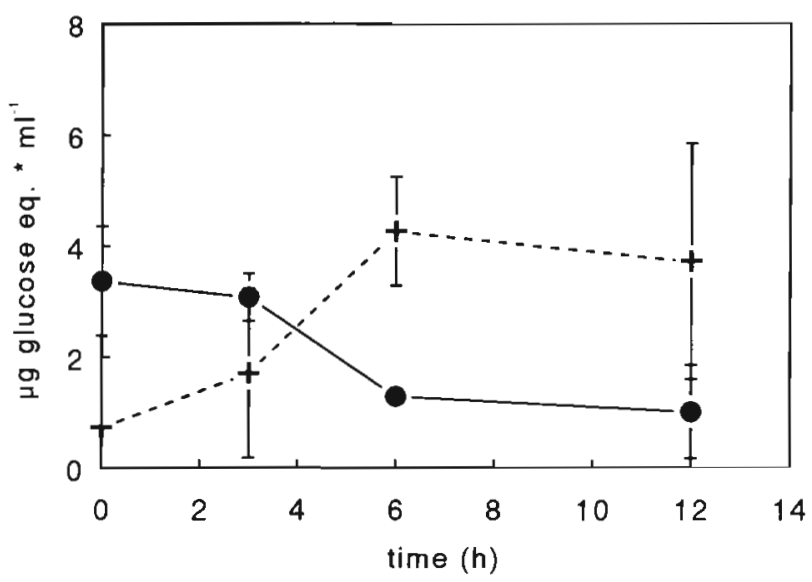

Fig. 4. Concentrations of polysaccharide (-) and LMW carbohydrate $(+)$ in an extract of attached extracellular carbohydrate separated from cells grown at a $12 \mathrm{~h}$ light: $12 \mathrm{~h}$ dark cycle. Values are mean $\pm \mathrm{SD}$ of 3 replicate bottles 
saccharide remained constant during the first hours. Measurements of oxygen depth profiles performed after application of DCMU showed that oxygen production was completely inhibited (S. van Bergeijk pers. comm.). However, towards the end of emersion concentrations significantly increased $(p<0.05)$, probably because by this time DCMU had diffused out of the sediment or became otherwise inactive. During the period of inundation (15:30 to 20:00 h) no samples were taken. After inundation the concentration of waterextractable polysaccharide in the control plot had decreased considerably $(p<0.05)$. During tidal emersion at night, the concentration continued to decrease significantly $(p<0.05)$.

The concentration of LMW carbohydrates in the water-soluble extract was quite high compared to polysaccharide concentrations (Fig. 5b). At the start of emersion concentrations did not differ between plots, but during emersion concentrations remained significantly higher in the light than in the plots that were darkened or treated with DCMU $(p<0.05)$. After tidal immersion, this pool had not decreased significantly, but during the night no clear pattern was found.

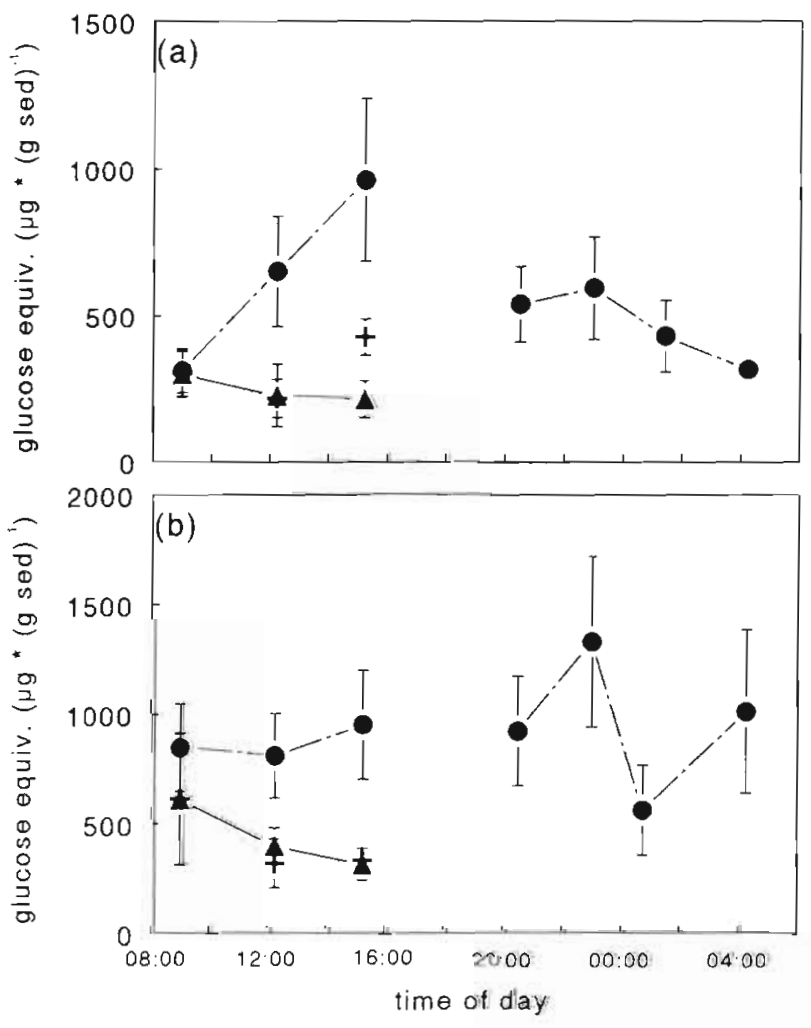

Fig. 5. (a) Water-extractable polysaccharide and (b) LMW carbohydrate in the upper $2.5 \mathrm{~mm}$ of sediment during emersion of a tidal flat in the Westerschelde in a plot treated with DCMU (+), a darkened plot ( $\mathbf{A}$ ) and a control plot ( $)$. Values are mean \pm SD of 10 replicate cores
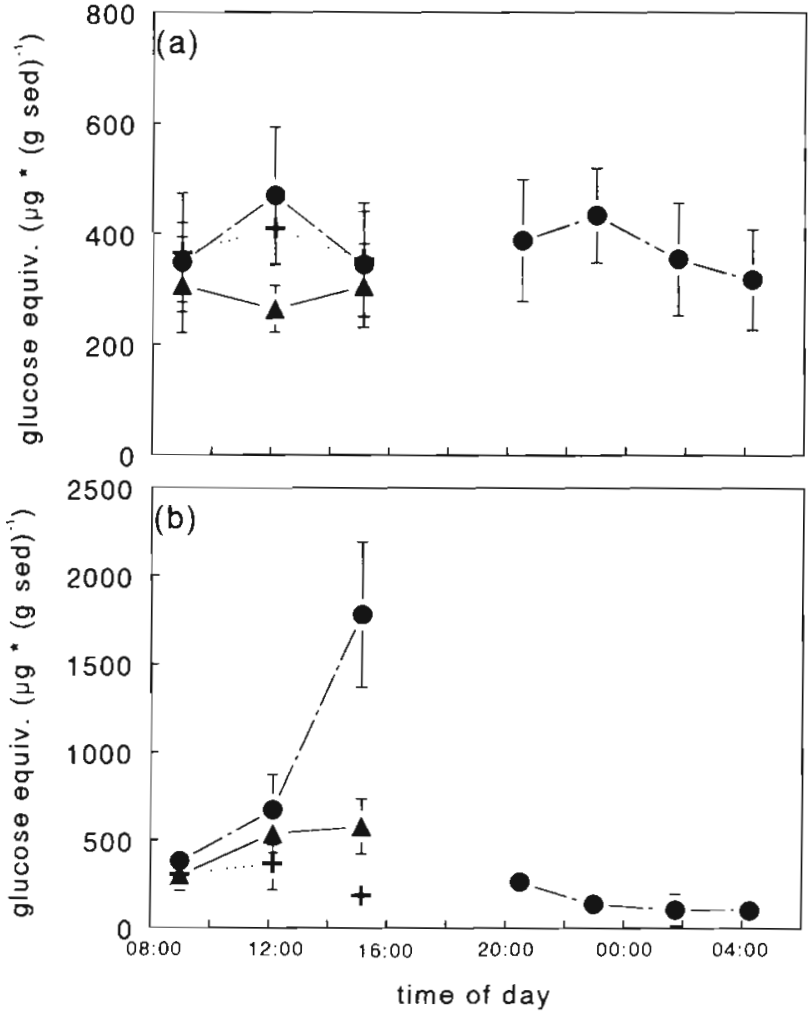

Fig. 6. (a) EDTA-extractable polysaccharide and (b) LMW carbohydrate in the upper $2.5 \mathrm{~mm}$ of sediment during emersion of a tidal flat in the Westerschelde in a plot treated with DCMU (+), a darkened plot ( $(\Delta)$ and a control plot $(\mathbf{O})$. Values are mean $\pm \mathrm{SD}$ of 10 replicate cores

At the start of emersion, the concentration of EDTAextractable polysaccharide was in the same order of magnitude as water-extractable polysaccharide, but this fraction showed no significant changes during a $24 \mathrm{~h}$ cycle (Fig. 6a). However, the LMW carbohydrates in the EDTA extract showed a pronounced increase in the light $(p<0.01)$, but not in the darkened or in the DCMU-treated sediment (Fig. 6b). In the light, this fraction increased approximately 5-fold over a $6 \mathrm{~h}$ period, up to a concentration higher than observed for any other fraction analyzed. After tidal inundation virtually all of this material had disappeared.

\section{DISCUSSION}

Axenic cultures of Cylindrotheca closterium incubated in the dark secreted no exopolysaccharide, whereas when incubated in the light exopolysaccharide concentration incieased. Also, incubation in the light with oxygenic photosynthesis blocked by DCMU inhibited production of exopolysaccharides. Although cells had been incubated in the dark for $10 \mathrm{~h}$, the con- 
centration of intracellular storage carbohydrate was still high. Therefore, the fact that no polysaccharide was secreted in the dark would appear not to be attributable to depletion of intracellular carbohydrate reserve. The decrease in intracellular carbohydrate in the dark was not reflected in an increase in exopolysaccharide, indicating that intracellular carbohydrate was not converted to exopolysaccharide in the dark but was probably respired. These results demonstrate that oxygenic photosynthesis is a prerequisite for secretion of polysaccharides. They contradict results reported by Smith \& Underwood (1998), who observed an increase in exopolysaccharide in darkness, corresponding to a decrease in intracellular storage carbohydrate. Interestingly, exopolysaccharide accumulation was especially high during the first $2 \mathrm{~h}$ after transfer to light. This could not be explained merely by light functioning as a trigger, since in the DCMUtreated culture no secretion was observed. Possibly, when cells were transferred from dark to light, secretion functioned as a sink for excess photosynthate, and photosynthate production was adjusted upon prolonged incubation. The fact that a certain minimum light intensity was required for secretion confirmed that such an overflow metabolism may be a steering factor for exopolysaccharide production.

The same treatments (light, dark, DCMU) were applied to natural diatom communities in situ. To compare exopolysaccharide production in culture and in the field, an important issue was to what extent carbohydrate fractions extracted from cultured cells and from sediment could be compared. While extraction from cultures was performed on fresh cells, sediment samples were stored at $-20^{\circ} \mathrm{C}$ and freeze-dried prior to extraction. Underwood et al. (1995) found that extraction with water on freeze-dried sediment may lead to contamination of the extract with intracellular carbohydrate. However, the storage carbohydrate of benthic diatoms, chrysolaminarin (Beattie et al. 1961, Darley 1977), is a polymer that does not precipitate in cold ethanol (Myklestad 1988, Staats et al. 1999). Therefore, if cell lysis had occurred during an extraction, this polymer would have been obtained in the LMW fraction of the extract. Therefore it was concluded that polysaccharide in the water extract from sediments could be quantitatively compared to polysaccharide in the water extract from cultures. These polysaccharides were the product of secretion (Taylor \& Paterson 1998, Underwood \& Smith 1998, Staats et al. 1999). Remarkably, LMW carbohydrates in the EDTA extract showed a pronounced increase in the light and, hence, were probably also a product of photosynthesis. Possibly, cell lysis occurred upon extraction with EDTA, and the LMW carbohydrate consisted of chrysolaminarin. The concentration of this material decreased considerably during tidal inundation, suggesting that this material may have been used by the diatoms as a carbon source for respiration (Myklestad 1988, Smith \& Underwood 1998).

The field situation represented a much more complex system than an axenic culture of Cylindrotheca closterium. Nevertheless, the experiments in which natural sediments were subjected to dark conditions or treatment with DCMU also showed that in the field no exopolysaccharide was produced in the dark or upon treatment with DCMU. This indicates that the dependence of polysaccharide secretion on photosynthesis was not a culture artefact. Furthermore, a decrease of polysaccharide in the water extract was found in the dark, both in culture (when grown under an alternating light:dark cycle) and in the field. The decrease observed in the field after tidal inundation may have been due to wash-out by the tide. This was also observed by Underwood \& Smith (1998). In contrast, Grant et al. (1986) found that diatoms were washed away by the tide while the exopolysaccharide matrix remained more or less intact. Alternatively, polysaccharides were possibly subject to hydrolysis. This was supported by the facts that (1) during emersion in the night the amount of polysaccharide also decreased (consistent with result reported by Van Duyl et al. 1999), and (2) no wash-out of LMW carbohydrate was observed. In the $C$. closterium culture grown under an alternating light:dark cycle, a decrease of exopolysaccharide was observed during the dark period as well. Since no bacteria were present in culture, it was conceived that the diatom itself was capable of hydrolysis of extracellular polysaccharide. A substantial amount of protein was observed in the extract (Staats et al. 1999), but it remained unclear whether these were an integral part of the exopolymer or consisted of secreted enzymes. When degradation of exopolysaccharide was monitored in an extract incubated separate from cells, it was accompanied by an increase in LMW carbohydrate. However, when cells were present (i.e. in the light:dark grown culture), the decrease in exopolysaccharide was accompanied by a decrease in LMW carbohydrate, suggesting that the hydrolysis product was taken up. Chemoheterotrophic growth has been encountered frequently in benthic diatoms (Hellebust \& Lewin 1977). This may be an important adaptation for benthic phototrophic organisms that are often, though irregularly, exposed to long periods of darkness, while concentrations of organic carbon are high in intertidal muddy sediments. Indeed, Saks et al. (1976) demonstrated that $C$. closterium is a facultative heterotroph. Although secretion of hydrolytic enzymes has been demonstrated for some benthic diatoms that appeared to be able to digest macromolecules such as agar, casein and cellulose (Lewin \& Lewin 1960. 
Hellebust \& Lewin 1977, Tanaka \& Ohwada 1988), no reports have been made of diatoms that were able to hydrolyze their own secretion product (Tuchman 1996).

It was not clear why degradation of polysaccharides in the dark in cultures of Cylindrotheca closterium was observed when cells were grown under an alternating light:dark cycle, but not when cells had previously been grown in continuous light. An explanation for this may be that continuous light-grown cells do not convert to heterotrophic growth very rapidly, as has been observed for glucose and lactate uptake in Cyclotella cryptica and Cylindrotheca fusiformis, respectively (Lewin \& Hellebust 1970, Hellebust 1971). These species showed a lag period of about $1 \mathrm{~d}$ before transport systems were induced. In contrast, light:dark grown cells may be adjusted to the recurring dark period. However, to gain more insight into the possibility that, under conditions unfavourable for photosynthesis, benthic diatoms are able to take up their own secretion product, more information is needed on secretion of hydrolytic enzymes.

Exopolysaccharides play a role in cell locomotion (Edgar \& Pickett-Heaps 1984). The exopolysaccharide matrix attaches the cell to a substratum, which is a prerequisite for movement. (Wetherbee et al. 1998). The question remains, however, to what extent other factors (e.g. overflow metabolism) play a role in steering exopolysaccharide production. For example, the amount of polysaccharide secreted depended on the growth status of the cells in studies by Sutherland et al. (1998) and Staats et al. (1999). During our field study, upward migration of diatoms at the start of daytime emersion was observed by the brown coloration of the sediment surface both in the light and in the dark plots. Indeed, Hopkins (1966) already showed that upward migration took place even when sediment was darkened, and Serodio et al. (1997) showed that diatoms continue to migrate upwards at the start of subjective daytime emersion when incubated in the dark for a number of days. This suggests that the observed differences in exopolysaccharide accumulation between the treatments were not likely to be due to differences in motility. Indeed, Edgar \& PickettHeaps (1984) concluded that no large amounts of polysaccharide have to be secreted for motility, hence other factors, such as overflow metabolism, may enhance secretion of polysaccharide during daytime emersion. Ruddy et al. (1998) calculated that the accumulation of carbohydrate in the sediment during emersion may well be the result of excess carbon fixation due to nitrogen limitation. There may be additional benefits in secretion of polysaccharides, such as protecting cells against resuspension or desiccation. This conclusion is not in line with the work of Smith \&
Underwood (1998), who concluded that exopolysaccharide production was closely linked to migratory rhythms.

In summary, secretion of polysaccharide by Cylindrotheca closterium occurred in the light but not in the dark. No exopolysaccharide was produced when photosynthesis was inhibited. The amount of polysaccharide secreted was dependent on light intensity. All these observations indicated that polysaccharide secretion was dependent on photosynthesis. The results suggest that overflow metabolism was a steering factor for secretion, and that exopolysaccharide was not only produced for motility. The dependence of polysaccharide secretion on photosynthesis was not only observed in monocultures, but also in a natural diatom population.

Acknowledgements. We thank $\mathrm{H}$. Peletier (RIKZ, Haren, The Netherlands) for providing a culture of Cylindrotheca closterium. S. van Bergeijk and C. van der Zee are acknowledged for assistance with field sampling. This investigation was financially supported in part by BOA research theme on tidal areas with financial aid from the Dutch Foundation for Scientific Research (NWO) and by the European Commission Mast III programme, contract MAS3-CT95-0022 (INTRMUD). This is publication 2543 of NIOO-CEMO

\section{LITERATURE CITED}

Beattie A, Hirst EL, Percival E (1961) Studies on the metabolism of the Chrysophyceae. Comparative structural investigations on leucosin (chrysolaminarin) separated from diatoms and laminarin from the brown algae. Biochem $\mathrm{J}$ $79: 531-537$

Dade WB, Davis JD, Nichols PD, Nowell ARM, Thistle D, Trexler MB, White DC (1990) Effects of bacterial exopolymer adhesion on the entrainment of sand. Geomicrobiol $\mathrm{J}$ 8:1-16

Darley WM (1977) Biochemical composition. In: Werner D (ed) The biology of diatoms. Blackwell Scientific Publications, Oxford, p 198-223

Decho AW (1990) Microbial exopolymer secretions in ocean environments: their role(s) in food webs and marine processes. Oceanogr Mar Biol Annu Rev 28:73-153

De Winder B, Staats N, Stal LJ, Paterson DM (1999) Carbohydrate secretion by phototrophic communities in tidal sediments. J Sea Res 42:131-146

Dubois M, Gilles KA, Hamilton JK, Rebers PA, Smith F (1956) Colorimetric methods for determination of sugars and related substances. Anal Chem 28:350-356

Edgar LA, Pickett-Heaps JD (1984) Diatom locomotion. In Round FE, Chapman G (eds) Progress in phycological research, Vol 3. Biopress Ltd, Bristol, p 47-88

Fenchel T, Straarup BJ (1971) Vertical distribution of photosynthetic nigments and the penetration of light in marine sediments Oikos 22:172-182

Grant J, Bathmann UV, Mills EL (1986) The interaction between benthic diatom films and sediment transport. Estuar Coast Shelf Sci 23:225-238

Harper MA (1977) Movements. In: Werner D (ed) The biology of diatoms. Blackwell Scientific Publications, Oxford, p 224-249 
Hellebust JA (1971) Giucose uptake by Cyclotella cryptica dark induction and light inactivation of transport system. J Phycol 7:345-349

Hellebust JA, Lewin J (1977) Heterotrophic nutrition. In Werner D (ed) The biology of diatoms. Blackwell Scientific Publications, Oxford, p 169-197

Herbert D, Phipps PJ, Strange RE (1971) Chemical analysis of microbial cells. In: Norris JR, Ribbons DW (eds) Methods in microbiology, Vol 5B. Academic Press, London, p 209-344

Hoagland KD, Rosowski JR, Gretz MR, Roemer SC (1993) Diatom extracellular polymeric substances: function, fine structure, chemistry and physiology. J Phycol 29:537-566

Holland AF, Zingmark RG, Dean JM (1974) Quantitative evidence concerning the stabilization of sediments by marine benthic diatoms. Mar Biol 27:191-196

Hopkins JT (1966) Some light-induced changes in behaviour and cytology of an estuarine mud-flat diatom. In: Bainbridge R, Evans GC, Rackham $O$ (eds) Light as an ecological factor. Symp Br Ecol Soc, Vol 5. Blackwell Scientific Publications, Oxford, p 335-358

Kester DR, Duedall IW, Connors N, Pytkowicz RM (1967) Preparation of artificial seawater. Limnol Oceanogr 12: $176-179$

Lewin J, Hellebust JA (1970) Heterotrophic nutrition of the marine pennate diatom Cylindrotheca fusiformis. Can J Microbiol 16:1123-1129

Lewin JC, Lewin RA (1960) Auxotrophy and heterotrophy in marine littoral diatoms. Can J Microbiol 6:127-134

McIntyre CD, Moore WW (1977) Marine littoral diatoms: ecological considerations. In: Werner D (ed) The biology of diatoms. Blackwell Scientific Publications, Oxford, p 333-371

Myklestad S (1977) Production of carbohydrates by marine planktonic diatoms. II. Influence of the N/P ratio in the growth medium on the assimilation ratio, growth rate, and production of cellular and extracellular carbohydrates by Chaetoceros affinis var. Willei (Gran) Hustedt and Skeletonema costatum (Grev.) Cleve. J Exp Mar Biol Ecol 29: $161-179$

Myklestad S (1988) Production, chemical structure, metabolism, and biological function of the $(1-3)$-linked, $\beta$-D-glucans in diatoms. Biol Oceanogr 6:313-326

Myklestad S, Haug A (1972) Production of carbohydrates by the marine diatom Chaetoceros affinis var. Willei (Gran) Hustedt. I. Effect of the concentration of nutrients in the culture medium. J Exp Mar Biol Ecol 9:125-136

Paterson DM (1989) Short-term changes in the erodibility of intertidal cohesive sediments related to the migratory behavior of epipelic diatoms. Limnol Oceanogr 34:223-234

Pinckney J, Zingmark RG (1991) Effects of tidal stage and sun angles on intertidal benthic microalgal productivity. Mar Ecol Prog Ser 76:81-89

Ruddy G, Turley CM, Jones TER (1998) Ecological interaction and sediment transport on an intertidal mudflat. I. Evi-

Editorial responsibility: Victor de Jonge (Contributing Editor), Haren, The Netherlands dence for a biologically mediated sediment-water interface. In: Black KS, Paterson DM, Cramp A (eds) Sedimentary processes in the intertidal zone. Special Publications. Geological Society, London, p 135-148

Saks NM, Stone RJ, Lee JJ (1976) Autotrophic and heterotrophic nutritional budget of salt marsh epiphytic algae. J Phycol 12:443-448

Serodio J, Da Silva JM, Catarino F (1997) Nondestructive tracing of migratory rhythms of intertidal benthic microalgae using in vivo chlorophyll a fluorescence. J Phycol 33: $542-553$

Smith DJ, Underwood GJC (1998) Exopolymer production by intertidal epipelic diatoms. Limnol Oceanogr 43: 1578-1591

Sokal RR, Rohlf FJ (1981) Biometry. Freeman and Co, San Francisco

Staats N, De Winder B, Stal LJ, Mur LR (1999) Isolation and characterization of extracellular polysaccharides from the epipelic diatoms Cylindrotheca closterium and Navicula salinarum. Eur J Phycol 34:161-169

Sutherland TF, Grant J, Amos CL (1998) The effect of carbohydrate production by the diatom Nitzschia curvilineata on the erodibility of sediment. Limnol Oceanogr 43:65-72

Tanaka N, Ohwada K (1988) Decomposition of agar, protein, and organic phosphate by marine epiphytic diatoms. Nippon Suisan Gakkaishi 54:725-727

Taylor IS, Paterson DM (1998) Microspatial variation in carbohydrate concentrations with depth in the upper millimetres of intertidal cohesive sediments. Estuar Coast Shelf Sci 46:359-370

Tuchman NT (1996) The role of heterotrophy in algae. In: Stevenson RJ, Bothwell MI, Lowe RL (eds) Algal ecology. Academic Press Inc, p 229-319

Underwood GJC, Smith DJ (1998) Predicting epipelic diatom exopolymer concentrations in intertidal sediments from sediment chlorophyll a. Microb Ecol 35:116-125

Underwood GJC, Paterson DM, Parkes RJ (1995) The measurement of microbial carbohydrate exopolymers from intertidal sediments. Limnol Oceanogr 40:1243-1253

Van Duyl FC, De Winder B, Kop AJ, Wollenzien U (1999) Tidal coupling between carbohydrate concentrations and bacterial activities in diatom-inhabited intertidal mudflats. Mar Ecol Prog Ser 191:19-32

Vos PC, De Boer PL, Misdorp R (1988) Sediment stabilization by benthic diatoms in intertidal sandy shoals; qualitative and quantitative observations. In: De Boer PL, Van Gelder A, Nio SD (eds) Tide-influenced sedimentary environments and facies. D Reidel, Dordrecht, p 511-526

Waite AM, Olson RJ, Dam HG, Passow U (1995) Sugar-containing compounds on the cell surfaces of marine diatoms measured using concanavalin $\mathrm{A}$ and flow cytometry. J Phycol 31:925-933

Wetherbee R, Lind JL, Burke J, Quatrano RS (1998) The first kiss: establishment and control of initial adhesion by raphid diatoms. J Phycol 34:9-15

Submitted: October 10,1998; Accepted: August 10, 1999

Proofs received from author(s): February 14, 2000 